\title{
PENERAPAN PROBLEM BASED LEARNING UNTUK HIGHER ORDER THINKING SKILLS PADA SISWA PENDIDIKAN TEKNIK INFORMATIKA
}

\author{
Satriyo Agung Dewanto ${ }^{1}$, Eko Marpanaji ${ }^{2}$, Muh Izzudin Mahali ${ }^{3}$, \\ Nur hasanah ${ }^{4} \&$ Bekti Wulandari ${ }^{5}$ \\ ${ }^{1,2}$ Universitas Negeri Yogyakarta \\ E-mail: satriyoad@uny.ac.id
}

\begin{abstract}
This research has purpose to know the difference between student learning result with computer network practice course and Higher Order Thinking Skill (HOTS) given by demonstration method with Problem Based Learning (PBL) method. This research is a research using quasi experiment consisting of two classes as sample. The one class uses the demonstration learning method, while the other class uses the PBL method. This study has an analysis using t-test. The result of this research is able to show there is difference between student learning outcomes with high thinking ability in computer network practice class among students given demonstration method with students given PBL method. Students who were given demonstration learning methods resulted less than students who had been provided with PBL methods in order to improve learning outcomes.
\end{abstract}

Keywords: learning methods, $P B L$, HOTS

\section{ABSTRAK}

Penelitian ini bertujuan untuk mengetahui perbedaan hasil belajar dan Higher Order Thinking Skill (HOTS) siswa pada mata kuliah praktik jaringan komputer melalui metode demonstrasi dan Problem Based Learning $(P B L)$. Penelitian ini merupakan quasi experiment yang terdiri dari dua kelas sebagai sampel. Satu kelas menggunakan metode pembelajaran demonstrasi, sedangkan kelas lainnya menggunakan metode PBL. Penelitian ini memiliki analisis menggunakan t-test. Hasil penelitian ini mampu menunjukkan ada perbedaan antara hasil belajar siswa dengan kemampuan berpikir tinggi pada kelas praktik jaringan komputer di antara siswa yang diberikan metode demonstrasi dengan siswa yang diberikan metode PBL. Siswa yang menggunakan metode demonstrasi memiliki peningkatan hasil belajar yang lebih rendah dari siswa yang menggunakan PBL.

Kata kunci: metode pembelajaran, PBL, HOTS

\section{PENDAHULUAN}

Program Studi Pendidikan Teknik Informatika Fakultas Teknik Universitas Negeri Yogyakarta mempunyai visi menjadi Program Studi terdepan Bidang Pendidikan Teknik Informatika di Indonesia yang mampu menghasilkan pendidik dan tenaga kependidikan dalam bidang teknik informatika yang bertakwa, mandiri, cendekia dan profesional pada tahun 2025. Program studi Pendidikan Teknik Informatika membuat langkah-langkah yang ada di dalam misi untuk mewujudkan visi tersebut. Salah satu misi untuk mewujudkannya adalah dengan meningkatkan penyelenggarakan pendidikan dan pengajaran dalam bidang teknik informatika untuk calon pendidik dan tenaga kependidikan.

Pembelajaran adalah proses komunikasi antara siswa dan pengajar serta semua unsur yang ada di sekitarnya. Dalam hal ini, pengajar memegang peranan yang sangat penting dalam menentukan unsur yang ada di dalamnya. Dalam peningkatan kualitas pembelajaran yang baik tentunya harus memiliki hasil yang baik juga. Permasalahan yang sering terjadi yaitu dalam pendidikan masih ada pandangan bahwa pengetahuan harus dihafalkan. Di sisi yang lain karena adanya banyak fakta bahwa pengajar atau pengajar menguasai suatu bidang materi dengan baik tetapi tidak melaksanakan 
kegiatan proses belajar mengajar dengan baik. Hal ini sering terjadi karena tidak berdasarkan pada metode pembelajaran yang sesuai, sehingga dapat menyebabkan hasil belajar siswa menjadi rendah. Ceramah yang dilakukan pengajar masih menjadi dominasi dimana proses belajar mengajar dilaksanakan.

Perkembangan jaman yang sangat pesat dengan kemajuan teknologi informasi yang berkembang sangat pesat, komputer dan jaringan komputer akan menghubungkan user ke seluruh dunia dan saat ini dikenal sebagai sistem jaringan internasional atau international networking yang akhirnya disingkat sebagai internet. Internet saat ini sudah menjadi sistem wajib yang dipasang oleh semua sektor untuk membantu kelancaran dalam hal komunikasi dan komputerisasi. Dikarenakan sangat pentingnya internet ini, maka disiapkan kompetensi jaringan komputer dalam kurikulum Program Studi Pendidikan Teknik Informatika.

Mata kuliah praktik jaringan komputer sebagai mata kuliah wajib pada kompetensi program studi pendidikan teknik informatika. Mata kuliah ini diberikan kepada siswa pada semester 4. Saat ini di lapangan sering menggunakan peralatan jaringan, instalasi LAN dan internet, pengetesan jaringan, subnetting, vlan, routing, dan bloking, sehingga mata kuliah ini harus mampu dikuasai siswa guna menyiapkan kompetensi yang sesuai dengan kebutuhan lapangan. Kompetensi yang harus dikuasai siswa adalah mendeskripsikan arti dari jaringan dan mengenal jaringan LAN, memasang konektor RJ-45 pada kabel UTP dan menguji kualitas kabel UTP, membangun LAN, melakukan konfigurasi IP Address di komputer jaringan serta memahami konsep alokasi IP public dengan metode Classless Adressing, subnetting dan routing, dapat melakukan teknik penggunaan subnet mask dan teknik subnetting menggunakan metode VLSM, melakukan pengetesan pengujian koneksi jaringan, menganalisa teknologi wireless (nirkabel) untuk membangun LAN dan koneksi internet, menganalisa dan mendesain keamanan jaringan.

Hasil dari interview dengan pengajar mata kuliah praktik jaringan komputer pada tanggal 13 Februari 2017, diperoleh informasi tentang hasil ujian akhir semester 4 tahun 2015/2016. Berdasarkan hasil wawancara ini, didapat masih banyak siswa yang nilainya di bawah B. Perolehan ujian akhir yang masih banyak di bawah B ini didasari oleh beberapa penyebab, salah satu penyebabnya adalah motivasi belajar siswa. Motivasi belajar adalah dorongan yang timbul dari dalam dan luar individu untuk melakukan perubahan tingkah laku. Motivasi belajar menentukan tingkat pencapaian prestasi belajar siswa ${ }^{(1)}$. Motivasi belajar yang ada dalam diri siswa yang satu dengan yang lain tidaklah sama, tentu saja ada yang mempunyai motivasi belajarnya tinggi dan ada juga yang mempunyai motivasi belajarnya rendah. Disamping itu, dalam proses pembelajaran masih berorientasi pada penugasan yang dirancang oleh pengajar dengan cara pengajaran yang masih konvensional. Dominasi pengajar yang sangat kuat membuat terabaikannya kesempatan siswa untuk terlibat aktif dalam pembelajaran sehingga siswa kurang kreatif. Kegiatan siswa hanya memperhatikan pengajar yang sedang mendemostrasikan materi pelajaran serta mencatat hal-hal yang sekiranya penting. Dalam proses pembelajaran, siswa dihadapkan pada tugas pemrograman yang sudah ada di dalam jobsheet. Tugas tersebut dikerjakan secara berkelompok dan sudah didemonstrasikan oleh pengajar sehingga siswa kurang mengetahui kejelasan tugas yang diberikan. Oleh sebab itu, pengajar harus mempunyai kreativitas tinggi dalam memilih metode pembelajaran yang menarik minat siswa.

Perlu pemilihan metode pembelajaran yang sesuai dengan situasi dan kondisi siswa serta lingkungan belajar, siswa dapat aktif, interaktif dan kreatif dalam proses pembelajaran agar upaya peningkatan/ penuntasan hasil belajar dapat berhasil. Pemilihan metode pembelajaran yang tepat 
merupakan manifestasi dari kreatifitas seorang pengajar agar siswa tidak jenuh atau bosan dalam menerima mata kuliah. Pemilihan metode pembelajaran yang tepat juga akan memperjelas konsep-konsep yang diberikan kepada siswa senantiasa antusias berfikir dan berperan aktif. Metode pembelajaran yang digunakan pengajar seharusnya dapat membantu proses analisis siswa. Sebagai tambahan, Prodi Pendidikan Teknik Informatika menekankan lulusannya menguasai kompetensi pedagogik. Melalui penerapan model pembelajaran yang dapat mengembangkan keterampilan berfikir di kelas, maka dapat memfasilitasi pemerolehan pengalaman menerapkan model tersebut untuk selanjutnya dapat digunakan saat menjadi pendidik kepada peserta didiknya ${ }^{(2)}$.

Salah satu metode tersebut adalah metode pembelajaran Problem Based Learning $(P B L)$. Diharapkan metode PBL lebih efektif bila dibandingkan dengan metode sebelumnya. Keefektifan metode ini adalah siswa lebih aktif dalam berfikir dan memahami materi secara berkelompok dengan melakukan investigasi dan inquiri terhadap permasalahan yang nyata di sekitarnya sehingga mereka mendapatkan kesan yang mendalam dan lebih bermakna tentang apa yang mereka pelajari.

Metode PBL merupakan salah satu metode pembelajaran dimana authentic assesment (penalaran yang nyata atau konkret) dapat diterapkan secara komprehensif, sebab didalamnya terdapat unsur menemukan masalah dan sekaligus memecahkannya (unsur terdapat didalamnya yaitu problem possing atau menemukan permasalahan dan problem solving atau memecahkan masalah). Tujuan dari PBL untuk menantang siswa mengajukan permasalahan dan juga menyelesaikan masalah yang lebih rumit dari sebelumnya, dapat meningkatkan keaktifan siswa dalam mengemukakan pendapatnya, menggalang kerjasama dan kekompakan siswa dalam kelompok, mengembangkan kepemimpinan siswa serta mengembangkan kemampuan pola analisis dan dapat membantu siswa mengembangkan proses berfikir. PBL digunakan untuk merangsang berfikir tingkat tinggi dalam situasi berorientasi masalah, termasuk belajar bagaimana belajar. Pengajaran berbasis masalah tidak dapat dilaksanakan jika pengajar tidak mengembangkan lingkungan kelas yang memungkinkan terjadinya pertukaran ide secara terbuka. Intinya, siswa dihadapkan pada situasi masalah yang otentik dan bermakna yang dapat menantang siswa untuk memecahkannya.

Berdasarkan latar belakang yang dibahas sebelumnya, peneliti ingin melihat penerapan problem based learning untuk menumbuhkan aspek kemampuan berfikir tingkat tinggi (Higher Order Thinking Skill) dan hasil belajar siswa prodi pendidikan teknik informatika pada mata kuliah praktik jaringan komputer. Mengacu pada permasalahan yang dibahas, maka penelitian ini bertujuan untuk mengetahui: (1) Ada tidaknya perbedaan Higher Order Thinking Skill siswa pada mata kuliah praktik jaringan komputer antara siswa yang diajar dengan metode PBL dengan siswa yang diajar dengan metode demonstrasi; dan (2) Ada tidaknya perbedaan hasil belajar siswa pada mata kuliah praktik jaringan komputer antara siswa yang diajar dengan metode PBL dengan siswa yang diajar dengan metode demonstrasi.

Problem-based learning

$(P B L)$ dipopulerkan oleh Barrow and Tamblyn pada tahun 1980 di Kanada ${ }^{(3)}$. Metode ini digunakan karena Barrow dan Tamblyn menemukan beberapa siswa yang tidak mampu mengaplikasikan pengetahuan yang telah diperolehnya dari proses belajar dalam menghadapi masalah kehidupan sehari-hari. $P B L$ merupakan metode dengan menghadapkan siswa pada permasalahanpermasalahan dunia nyata. Seperti yang dikemukakan Barbara (4) "Problem Based Learning is an instructional method that encourages learners to apply critical thinking, problem-solving skills, and content knowledge to real-world problems and issue". $P B L$ dimulai dengan suatu isu, kasus, atau masalah 
yang mengambang, kemudian siswa memecahkan masalah dengan solusi yang didapatkannya melalui stimulus dalam proses belajar. $P B L$ adalah suatu metode pembelajaran dimana pengajar memberikan tugas berupa masalah yang masih mengambang kemudian siswa mencari solusi untuk memecahkan masalah yang diberikan. Dalam pencarian solusi ini siswa juga mencari pengetahuan sendiri. Pengertian tersebut dikuatkan oleh pendapat Linda dan Sara ${ }^{(5)}$ bahwa $P B L$ dipusatkan pada penyelidikan yang berhubungan dengan dunia nyata. Metode PBL melibatkan siswa sebagai stakeholders didalam situasi masalah. Tan ${ }^{(6)}$ menjelaskan bahwa " $P B L$ is recognized as a progressive active-learning and learnercentered approach where unstructured problems (real-world or simulated complex problems) are used as the starting point and anchor for the learning process". PBL merupakan pembelajaran yang berpusat pada masalah yang tidak terstruktur yang digunakan sebagai titik awal dalam proses pembelajaran. Glazer ${ }^{(7)}$ mengemukakan bahwa: "Problembased learning is an instructional strategy in which students actively resolve complex problems in realistic situations. It can be used to teach individual lessons, units, or even entire curricula. PBL is often approached in a team environment with emphasis on building skills related to consensual decision making, dialogue and discussion, team maintenance, conflict management, and team leadership".

PBL merupakan pembelajaran yang membuat siswa aktif untuk memberikan solusi pada permasalahan dalam situasi nyata, pembelajaran tersebut bisa digunakan untuk mengajarkan pelajaran yang bersifat individu, unit, atau bahkan seluruh kurikulum. Menurut Howard Barrows dan Kelson ${ }^{(8)}$, PBL adalah kurikulum dan proses pembelajaran. Dalam kurikulumnya, dirancang masalah-masalah yang menuntut siswa mendapatkan pengetahuan yang penting, membuat mereka mahir dalam memecahkan masalah, dan memiliki strategi belajar sendiri serta berpartisipasi dalam tim. Proses pembelajarannya menggunakan pendekatan yang sistematik untuk memecahkan masalah atau menghadapi tantangan yang nanti diperlukan di dalam kehidupan sehari-hari. Jadi PBL adalah pemberian masalah yang berhubungan dengan kehidupan sehari-hari kepada siswa kemudian siswa secara berkelompok mencari alternatif solusi untuk menyelesaikan masalah tersebut. Sedangkan menurut Dutch ${ }^{(8)}$ problem based learming merupakan metode instruksional yang menantang siswa agar belajar untuk belajar, bekerja sama dalam kelompok untuk mencari solusi bagi masalah yang nyata masalah ini diguakan untuk mengingatkan rasa keingintahuan serta kemampuan analitis dan inisiatif atas materi pelajaran. $P B L$ mempersiapkan siswa untuk berpikir kritis dan analisis dan untuk mencari dan menggunakan sumber pembelajaran yang sesuai.

Dari pendapat para ahli tersebut, maka dapat ditarik kesimpulan bahwa metode PBL adalah metode pembelajaran yang dimulai dari permasalahan yang masih mengambang dimana siswa akan membangun konsep dari pemecahan masalah dengan kemampuan sendiri dan kelompok yang mengintregasikan ketrampilan dan pengetahuan yang sudah dipahami sebelumnya. Pemahaman konsep dan pemecahan masalah merupakan perlu ditekankan dalam pencapaian tujuan belajar khususnya untuk materi yang memiliki unsur penguasaan materi dasar untuk melakukan analisis pada keterampilan teknis lanjut ${ }^{(9)}$, dalam hal ini pada materi mata kuliah praktik jaringan computer.

Maastricht ${ }^{(10)}$, menjelaskan bahwa ada tujuh tahapan dalam metode PBL yaitu: "(1) clarify the concepts; (2) define the problem; (3)analyse the problem; (4) find the explanation; (5) formulate the learning objective; (6) search for further information; (7) report and test new information". Tahapan-tahapan yang harus dilakukan oleh siswa yaitu memahami konsep, menentukan masalah, menganalisa masalah, menemukan penjelasan, menentukan tujuan pembelajaran, 
mencari informasi lebih banyak dan mempresentasikan hasil.

Dari uraian di atas, langkah-langkah metode problem based learning dalam penelitian mata pelajaran praktik jaringan komputer yaitu: (1) Memberikan permasalahan kepada siswa dimana permasalahan tersebut berhubungan dengan kehidupan sehari-hari; (2) Pengajar mengorganisasikan siswa dalam beberapa kelompok; (3) Pengajar membantu siswa mengorganisasikan tugas belajar sesuai dengan masalah; (4) Siswa mengumpulkan pengetahuan dan melakukan percobaan sesuai dengan pemecahan masalah yang diberikan. Dalam hal ini mempersiapkan siswa untuk berpikir kritis, analisis dan untuk mencari serta menggunakan sumber pembelajaran yang sesuai; (5) Siswa mengembangkan dan menyajikan hasil karya yang berupa suatu program.

Ball \& Garton (2005) dan Aksela (2005) (11) menyatakan bahwa kompetensi berpikir dapat dikelompokkan menjadi dua, yaitu kompetensi berpikir tingkat rendah (lower order thingking/LOW) dan kompetensi berpikir tingkat tinggi (higher order thingking/HOT). Kompetensi berpikir tingkat rendah meliputi mengingat, menghafal, dan sedikit memahami sedangkan kompetensi berpikir tingkat tinggi adalah kegiatan mental dalam memecahkan masalah dalam tingkat yang lebih tinggi dari tingkat berpikir dasar. Kompetensi berpikir dapat dikelompokkan menurut Taksonomi Bloom ${ }^{(12)}$, seperti pada Tabel 1.

\begin{tabular}{ccc}
\multicolumn{2}{c}{ Tabel 1. Pengklasifikasian kompetensi berpikir menurut } & Taksonomi Bloom ${ }^{(12)}$ \\
\hline Taksonomi Bloom & Tingkatan Berpikir & Tinjauan \\
\hline Knowledge $(\mathrm{C} 1)$ & Lower-order & Mengingat \\
Comprehension (C2) & Lower-order & Memahami \\
Application (C3) & Higher-order & Menerapkan \\
Analysis (C4) & Higher-order & Menganalisis \\
Synthesis (C5) & Higher-order & Menciptakan \\
Evaluation (C6) & Higher-order & Mengevaluasi \\
\hline
\end{tabular}

Masing-masing tingkatan dalam kompetensi berpikir tingkat tinggi adalah sebagai berikut: (1) Tingkat Aplikasi (aplication level). Tingkat aplikasi mencakup beberapa kemampuan, antara lain: (a) menggunakan informasi; (b) menggunakan metode, konsep, teori dalam permasalahan baru; dan (c) menyelesaikan masalah menggunakan pengetahuan dan kemampuan yang diperlukan; (2) Tingkat Analisis (analysis level). Tingkat analisis mencakup beberapa kemampuan, antara lain: (a) melihat polanya; (b) mengorganisasi bagiannya; (c) mengenal pengertian yang tersembunyi; dan (d) mengidentifikasi komponen; (3) Tingkat Sintesis (synthesis level). Tingkat sintesis mencakup beberapa kemampuan, antara lain: (a) menggeneralisasi fakta-fakta yang diberikan; (b) menghubungkan pengetahuan dai beberapa area; (c) memprediksi, menarik kesimpulan; dan (d) menggunakan ide lama untuk menciptakan hal yang baru; serta (4) Tingkat Evaluasi (evaluation level). Tingkat evaluasi mencakup beberapa kemampuan, antara lain: (a) memberi penilaian terhadap teori; (b) membuat pilihan berdasarkan pertimbangan pemikiran; (c) memperivikasi nilai bukti; (d) mengenal kesubyektifan; dan (e) membandingkan dan membedakan antara gagasan.

\section{METODE}

Jenis penelitian ini menggunakan pendekatan kuantitatif, karena dalam menganalisis data menggunakan data-data numerikal atau angka yang diolah dengan metode statistik, setelah diperoleh hasilnya, kemudian dideskripsikan dengan menguraikan kesimpulan yang didasari oleh angka yang diolah dengan metode statistik tersebut. 
Adapun desain penelitiannya adalah quasi experiment. Quasi experiment merupakan eksperimen yang mempunyai unsur perlakuan, pretest, dan posttest tetapi tidak mengambil sampel secara random. Pembandingan tergantung pada kelompok-kelompok nonekuivalen ${ }^{(13)}$. Desain quasi eksperiment yang digunakan adalah non equivalent control group design karena tidak mengacak kelaskelas yang telah ada di tempat penelitian sehingga kelompok yang dibandingkan mengambil dari kelas-kelas yang telah ada. Desain ini melibatkan kelas eksperimen dan kelas kontrol. Kelas eksperimen menggunakan metode $P B L$ dan kelas kontrol menggunakan metode pembelajaran yang telah diterapkan. Sebelum diberikan perlakuan dalam bentuk metode pembelajaran kedua kelompok diberi pretest dan setelah diberikan perlakuan metode pembelajaran kedua kelompok diberi posttest untuk mengetahui hasil belajar siswa.

Populasi penelitian ini adalah siswa prodi pendidikan teknik informatika semester 4. Penelitian ini membutuhkan dua kelas yaitu satu kelas diberikan metode PBL (kelas eksperimen) dan satu kelas diberikan metode pembelajaran demonstrasi (kelas kontrol). Pemilihan jenjang semester 4 sebagai subjek penelitian adalah karena mata kuliah praktik jaringan komputer diberikan pada jenjang tersebut. Teknik pengambilan sampel dilakukan dengan teknik simple random sampling. Ini dilakukan karena pengambilan anggota sampel dari populasi dilakukan secara acak tanpa memperhatikan strata dalam populasi itu ${ }^{(14)}$. Penentuan sampel kelas yang diberikan perlakuan dilakukan dengan cara mengundi.

Beberapa hal yang dikontrol dalam validitas eksternal dan internal yaitu unsur kematangan, unsur peristiwa dalam proses pembelajaran, unsur subjek penelitian, unsur materi perlakuan, unsur tes, unsur mortalitas. Selain validitas internal, juga terdapat kontrol validitas eksternal. Kontrol validitas exsternal dilakukan dengan cara: (1) memilih sampel dengan karakteristik populasi dengan prosedur dan metodologis yang sesuai; (2) tidak mengubah jadwal saat melakukan proses pembelajaran; dan (3) pemantauan terhadap pelaksanaan eksperimen dilakukan secara terbuka.

Sebelum dilakukan penelitian pada kedua kelas, maka terlebih dahulu dilakukan uji kesamaan kemampuan awal pada kedua kelas tersebut. Data yang digunakan untuk menguji kesamaan kemampuan awal adalah dengan menggunakan nilai pretest (tes awal). Pretest diberikan pada kedua kelas pada saat sebelum diberikan perlakuan metode pembelajaran. Nilai pretest tersebut kemudian di analisis melalui hasil uji kesamaan kemampuan awal adalah uji-t. Pada analisis statistika deskriptif, skor hasil pretest dan posttest kelas eksperimen dan kelas kontrol dianalisis untuk mengetahui hasil deskripsi data yang diperoleh sebelum dan sesudah diterapkan perlakuan pembelajaran. Analisis statistika deskriptif dilakukan dengan menghitung nilai rerata (mean), variansi (variance), simpangan baku (standard deviation), nilai terendah data (minimum), dan nilai tertinggi (maximum) pada ketiga kelas.

Setelah dilakukan pemberian perlakuan pada kedua kelas, kelas eksperimen dan kelas kontrol, maka didapatkan data hasil belajar siswa, yang biasa disebut dengan postest. Data postest tersebut sebelum dilakukan analisis, maka data postest dikenai uji prasyarat analisis. Uji prasyarat analisis tersebut meliputi: (1) Uji Normalitas untuk mengetahui apakah populasi/sampel penelitian ini berasal dari populasi yang normal atau tidak. Uji ini dilakukan dengan uji Saphiro-Wilk dengan taraf signifikansi 5\%, dikarenakan untuk sampel kecil dengan ukuran data 10 sampai dengan 50, tes Saphiro-Wilk paling kuat dalam mendeteksi penyimpangan dari normalitas. Kriteria keputusan dalam uji ini jika sig $>0,05$ berarti subjek berasal dari populasi yang berdistribusi normal; dan (2) Uji Homogenitas untuk mengetahui apakah populasi penelitian mempunyai variansi yang sama atau tidak. Uji homogenitas menggunakan Levene test. Kriteria keputusan dalam uji ini jika sig $>0,05$ 
berarti kedua subjek berasal dari populasi yang mempunyai varians yang homogen.

Dalam penelitian ini, uji t dilakukan untuk mengetahui perbedaan hasil belajar dan kemampuan berfikir tingkat tinggi kelas eksperimen dengan kelas kontrol dan untuk mengetahui hasil belajar kelas eksperimen lebih baik daripada kelas kontrol. Hasil uji t dengan melihat nilai Sig (2 tailed $)$ dibandingkan dengan tingkat kepercayaan yang diambil, yaitu $\alpha=0,05$. Ketentuannya, jika nilai Sig $(2$ tailed $)<\alpha$ maka $\mathrm{H}_{0}$ ditolak dan $\mathrm{H}_{\mathrm{a}}$ diterima, begitu juga sebaliknya. Pengujian prasyarat analisis dan hipotesis menggunakan bantuan program komputer SPSS versi 16.0 for Windows.

\section{HASIL DAN PEMBAHASAN}

Tahapan pengujian awal subjek penelitian untuk mengetahui apakah kelas eksperimen dan kelas kontrol dalam keadaan seimbang atau tidak menggunakan nilai pretest. Hipotesis yang akan diuji dalam uji pretest ini adalah $\mathrm{H}_{0}$ : kemampuan awal antara kelas eksperimen dan kelas kontrol seimbang dan $\mathrm{Ha}$ : kemampuan awal antara kelas eksperimen dan kelas kontrol tidak seimbang. Jika nilai signifikansinya lebih dari 0,05 maka $\mathrm{H}_{0}$ diterima dan $\mathrm{Ha}$ ditolak, sebaliknya jika nilai signifikansinya kurang dari 0,05 maka $\mathrm{H}_{0}$ ditolak dan $\mathrm{Ha}$ diterima. Hasil analisis menunjukkan bahwa nilai sig. (2-tailed) sebesar 0,271 untuk kelas eksperimen dan kelas kontrol. Hal ini menunjukkan bahwa nilai signifikansi pengujian pretest lebih dari 0,05 sehinggga $\mathrm{H}_{0}$ diterima dan dapat disimpulkan bahwa kemampuan awal antara kelas eksperimen dan kelas kontrol seimbang. Uji prasyarat analisis dalam penelitian ini meliputi uji homogenitas data dan uji normalitas. Rangkuman hasil uji normalitas dapat dilihat pada Tabel 4, 5, dan 6 . Sedangkan rangkuman pengujian homogenitas variansi ditunjukkan dalam Tabel 7.

Tabel 4. Rangkuman Uji Normalitas Hasil Pretest dengan SPSS 16

\begin{tabular}{clcccc}
\hline No & \multicolumn{1}{c}{ Nama Variabel } & $\begin{array}{c}\text { Banyak } \\
\text { Sampel }(\mathrm{n})\end{array}$ & $\begin{array}{c}\text { Sig. } \\
(\rho)\end{array}$ & $\begin{array}{c}\text { Keputusan } \\
\text { Uji }\end{array}$ & Ket. \\
\hline 1 & Hasil Pretest yang akan dikenai metode PBL & 17 & 0,273 & Diterima & Normal \\
2 & $\begin{array}{l}\text { Hasil Pretest yang akan dikenai metode } \\
\text { demonstrasi }\end{array}$ & 19 & 0,710 & Diterima & Normal \\
\hline
\end{tabular}

Tabel 5. Rangkuman Uji Normalitas Hasil HOTS dengan SPSS 16

\begin{tabular}{clcccc}
\hline No & \multicolumn{1}{c}{ Nama Variabel } & $\begin{array}{c}\text { Banyak } \\
\text { Sampel }(\mathrm{n})\end{array}$ & $\begin{array}{c}\text { Sig. } \\
(\rho)\end{array}$ & $\begin{array}{c}\text { Keputusan } \\
\text { Uji }\end{array}$ & Ket \\
\hline 1 & Hasil belajar dengan metode PBL & 17 & 0,634 & Diterima & Normal \\
2 & Hasil belajar dengan metode demonstrasi & 19 & 0,099 & Diterima & Normal \\
\hline
\end{tabular}

Tabel 6. Rangkuman Uji Normalitas Hasil Belajar dengan SPSS 16

\begin{tabular}{llcccc}
\hline No & \multicolumn{1}{c}{ Nama Variabel } & $\begin{array}{c}\text { Banyak } \\
\text { Sampel }(\mathrm{n})\end{array}$ & $\begin{array}{c}\text { Sig. } \\
(\rho)\end{array}$ & $\begin{array}{c}\text { Keputusan } \\
\text { Uji }\end{array}$ & Ket \\
\hline 1 & Hasil belajar dengan metode PBL & 17 & 0,586 & Diterima & Normal \\
2 & Hasil belajar dengan metode demonstrasi & 19 & 0,446 & Diterima & Normal \\
\hline
\end{tabular}

Tabel 7. Hasil Uji Homogenitas

\begin{tabular}{cccccc}
\hline No & & Variabel & Sig & $\begin{array}{c}\text { Keputusan } \\
\text { Uji }\end{array}$ & Ket \\
\hline 1 & Pre-Test & $\begin{array}{l}\text { Homogenitas antara metode } P B L 1 \\
\left(\mathrm{~A}_{1}\right) \text { dengan metode demonstrasi }\left(\mathrm{A}_{2}\right)\end{array}$ & 0,323 & Diterima & Homogen \\
2 & HOTS & $\begin{array}{l}\text { Homogenitas antara metode } P B L 1 \\
\left(\mathrm{~A}_{1}\right) \text { dengan metode demonstrasi }\left(\mathrm{A}_{2}\right)\end{array}$ & 0,604 & Diterima & Homogen \\
3 & Hasil Belajar & $\begin{array}{l}\text { Homogenitas antara metode } P B L ~ \\
\left(\mathrm{~A}_{1}\right) \text { dengan metode demonstrasi }\left(\mathrm{A}_{2}\right)\end{array}$ & 0,497 & Diterima & Homogen \\
\hline
\end{tabular}


Hasil pengujian prasyarat analisis menunjukkan homogen dan berdistribusi normal. Pengujian hipotesis dalam penelitian ini tentang perbedaan kemampuan berfikir tingkat tinggi dan hasil belajar dari dua kelompok sampel, yaitu: kelompok yang dikenai metode pembelajaran Problem Based Learning $\left(\mathrm{A}_{1}\right)$ dan metode demonstrasi $\left(\mathrm{A}_{2}\right)$. Analisis data dalam penelitian ini menggunakan statistik parametrik dengan menggunakan Uji-t dan analisis dua jalan. Rangkuman hasil uji $\mathrm{T}$ disajikan dalam Tabel 8 .

Tabel 8. Rangkuman Hasil Uji T Data kemampuan berfikir tingkat tinggi siswa

\begin{tabular}{cccc}
\hline $\begin{array}{c}\text { Kemampuan berfikir } \\
\text { tingkat tinggi }\end{array}$ & $\mathrm{t}_{\text {hitung }}$ & df & $\begin{array}{c}\mathrm{Sig}(2- \\
\text { tailed })\end{array}$ \\
\hline $\begin{array}{c}\text { Kelas Eksperimen } \\
\text { dengan kelas Kontrol }\end{array}$ & 4,698 & 34 & 0,000 \\
\hline
\end{tabular}

Hipotesis yang diuji adalah:

$\mathrm{H}_{0}$ : Tidak terdapat perbedaan kemampuan berfikir tingkat tinggi siswa pada mata kuliah praktik jaringan komputer antara siswa yang diajar dengan metode PBL dengan siswa yang diajar dengan metode demonstrasi

Ha : Terdapat perbedaan kemampuan berfikir tingkat tinggi siswa pada mata kuliah praktik jaringan komputer antara siswa yang diajar dengan metode PBL dengan siswa yang diajar dengan metode demonstrasi.

Tabel 8 menunjukkan bahwa $\mathrm{p}(0,000)<$ 0,05 . Oleh karena itu, dapat disimpulkan bahwa Ho ditolak dan Ha diterima, yaitu terdapat perbedaan kemampuan berfikir tingkat tinggi siswa pada mata kuliah praktik jaringan komputer antara siswa yang diajar dengan metode PBL dengan siswa yang diajar dengan metode demonstrasi. Berdasarkan data kemampuan berfikir tingkat tinggi siswa, menunjukkan bahwa kemampuan berfikir tingkat tinggi siswa yang diajar dengan metode $P B L$ lebih tinggi dibandingkan dengan kemampuan berfikir tingkat tinggi siswa yang diajar dengan metode pembelajaran demonstrasi ( $\overline{\mathrm{X}} \mathrm{A}_{1}=87,05>\overline{\mathrm{X}} \mathrm{A}_{2}=74,86$ ). Rangkuman hasil uji $\mathrm{T}$ disajikan pada Tabel 9.
Tabel 9. Rangkuman Hasil Uji T Data hasil belajar siswa

\begin{tabular}{cccc}
\hline $\begin{array}{c}\text { Kemampuan berfikir } \\
\text { tingkat tinggi }\end{array}$ & $\mathrm{t}_{\text {hitung }}$ & df & $\begin{array}{c}\text { Sig(2- } \\
\text { tailed) }\end{array}$ \\
\hline $\begin{array}{c}\text { Kelas Eksperimen } \\
\text { dengan kelas Kontrol }\end{array}$ & 3,775 & 34 & 0,001 \\
\hline
\end{tabular}

Hipotesis yang diuji adalah :

$\mathrm{H}_{0}$ : Tidak terdapat perbedaan hasil belajar siswa pada mata kuliah praktik jaringan komputer antara siswa yang diajar dengan metode PBL dengan siswa yang diajar dengan metode demonstrasi.

Ha : Terdapat perbedaan hasil belajar siswa pada mata kuliah praktik jaringan komputer antara siswa yang diajar dengan metode PBL dengan siswa yang diajar dengan metode demonstrasi.

Tabel 9 menunjukkan bahwa $\mathrm{p}(0,001)<$ 0,05. Sehingga dapat disimpulkan bahwa $\mathrm{H}_{0}$ ditolak dan $\mathrm{Ha}$ diterima, yaitu terdapat perbedaan hasil belajar siswa pada mata kuliah praktik jaringan komputer antara siswa yang diajar dengan metode PBL dengan siswa yang diajar dengan metode demonstrasi. Berdasarkan data hasil belajar siswa, menunjukkan bahwa hasil belajar siswa yang diajar dengan metode $P B L$ lebih tinggi dibandingkan dengan hasil belajar siswa yang diajar dengan metode pembelajaran demonstrasi ( $\overline{\mathrm{X}} \mathrm{A}_{1}=80,05>\overline{\mathrm{X}} \mathrm{A}_{2}=70,02$ ). Rangkuman hasil uji T tersaji pada Tabel 10.

Tabel 10. Rangkuman Hasil Uji $\mathrm{T}$ Data Gain belajar siswa

\begin{tabular}{cccc}
\hline Hasil Belajar & $\mathrm{t}_{\text {hitung }}$ & df & $\begin{array}{c}\operatorname{Sig}(2- \\
\text { tailed) }\end{array}$ \\
\hline $\begin{array}{c}\text { Kelas Eksperimen } \\
\text { dengan kelas Kontrol }\end{array}$ & 3,154 & 34 & 0,003 \\
\hline
\end{tabular}

Hipotesis yang diuji adalah :

$\mathrm{H}_{0}$ : Tidak terdapat perbedaan gain hasil belajar antara siswa yang diajar dengan metode $P B L$ dengan siswa yang diajar dengan metode pembelajaran demonstrasi.

Ha : Terdapat perbedaan gain hasil belajar antara siswa yang diajar dengan metode $P B L$ dengan siswa yang diajar dengan metode pembelajaran demonstrasi.

Taraf signifikansi yang digunakan pada uji analisis varians dua jalan adalah sebesar 0,05. Tabel 10 menunjukkan bahwa menunjukkan bahwa $\mathrm{p}(0,000)<0,05$. Sehingga dapat disimpulkan bahwa $\mathrm{H}_{0}$ ditolak 
dan Ha diterima, yaitu terdapat perbedaan gain hasil belajar siswa pada mata kuliah praktik jaringan komputer antara siswa yang diberi pembelajaran dengan metode $P B L$ dengan siswa yang diajar dengan metode pembelajaran demonstrasi. Berdasarkan data hasil belajar siswa, menunjukkan bahwa peningkatan hasil belajar siswa yang diajar dengan metode $P B L$ lebih tinggi dibandingkan dengan hasil belajar siswa yang diajar dengan metode pembelajaran demonstrasi $\left(\overline{\mathrm{X}} \mathrm{A}_{1}=\right.$ $\left.36,62>\overline{\mathrm{X}} \mathrm{A}_{2}=24,48\right)$.

Hipotesis yang diajukan dalam penelitian ini menyatakan bahwa terdapat perbedaan kemampuan berfikir tingkat tinggi siswa dan hasil belajar siswa pada mata kuliah praktik jaringan komputer antara siswa yang diajar dengan metode $P B L$ dengan siswa yang diajar dengan metode pembelajaran demonstrasi diterima. Rata-rata hasil belajar metode $P B L$ lebih tinggi dibandingkan dengan rata-rata hasil belajar metode pembelajaran demonstrasi ( $\overline{\mathrm{X}} \mathrm{A}_{1}=87,05>\overline{\mathrm{X}} \mathrm{A}_{2}=74,86$ ). Rata-rata kemampuan berfikir tingkat tinggi metode $P B L$, apabila dikonversi dengan skor huruf adalah A. Hal ini menunjukkan bahwa metode $P B L$ lebih unggul dibandingkan dengan metode pembelajaran demonstrasi.

Pada metode $P B L$ bersifat student centered. Pada metode pembelajaran ini pengajar memberikan tugas berupa masalah yang masih mengambang kemudian siswa mencari solusi untuk memecahkan masalah yang diberikan. Dari berbagai masalah yang telah diberikan kemudian siswa merumuskan masalah tersebut dan mencari pemecahannya. Dalam hal ini siswa mampu menganalisis dan mengidentifikasi permasalahan yang diberikan. Dalam pemecahan masalah dilakukan dengan diskusi kelompok sehingga siswa dapat saling bertukar pikiran dan membagi ilmu dengan siswa lainya. Setelah masalah tersebut dapat dipecahkan dan dibuktikan ke dalam praktik, kemudian dilanjutkan dengan presentasi kelas. Pada presentasi ini akan terjadi diskusi dan pertukaran informasi kembali dalam kelompok satu kelas. Dari diskusi itu akan didapatkan pengalaman dan wawasan baru dan kadang ditemukan juga permasalahan permasalahan baru yang berkaitan untuk dipecahkan. Diskusi merupakan kegiatan pembelajaran yang dapat digunakan untuk mengembangkan pemecahan masalah ${ }^{(9)}$. Dalam pemecahan masalah ini siswa juga mencari pengetahuan sendiri karena peran pengajar hanya sebagai fasilitator bukan pentransfer pengetahuan. Sejalan dengan Adang ${ }^{(15)}$ bahwa, salah satu meningkatkan kemampuan berfikir tingkat tinggi adalah memberikan kesempatan kepada siswa untuk membaca buku-buku yang mendorong melakukan studi lebih lanjut, sehingga meskipun jawaban yang diperoleh tidak sama dengan yang ada di buku tetapi konsep yang digunakan benar.

Dalam kegiatan di atas, tidak terlepas dari membuat keputusan secara efektif yang dilakukan dengan menganalisa dan mengevaluasi berbagai altenarif, kemudian mensintesis dan mencoba membangun hubungan diantara informasi dan argument. Beberapa kegaitan di atas adalah tingkatan dari kemampuan berfikir tingkat tinggi. Kompetensi berpikir tingkat tinggi adalah kegiatan mental dalam memecahkan masalah dalam tingkat yang lebih tinggi dari tingkat berpikir dasar. Agar mampu memecahkan masalah dengan baik dan berkualitas tinggi dituntut kemampuan aplikasi, analisis, sintesis, evaluasi, generalisasi, membandingkan, mendeduksi, mengklasifikasi informasi, menyimpulkan, dan mengambil keputusan. PBL membangun kompetensi menerapkan informasi dan pengetahuan secara logis, kritis, kreatif, dan inovatif dalam pengambilan keputusan.

Pada metode pembelajaran demonstrasi, pengajar menyajikan materi dari awal sampai akhir dan peran pengajar sangat dominan dalam kegiatan belajar mengajar. Sebelum kegiatan praktikum, pengajar memperagakan kepada siswa melakukan konfigurasi IP Address dikomputer jaringan. Pada metode pembelajaran ini, kegiatan belajar belajar mengajar berpusat pada pengajar dan kurang 
memperhatikan keaktifan siswa. Peran siswa hanya sekedar memperhatikan apa yang didemonstrasikan oleh pengajar. Pada kegiatan praktik, siswa hanya melakukan praktik terencana sesuai dengan yang telah didemonstrasikan dan tertuang di dalam jobsheet.

Dengan menggunakan metode PBL, siswa akan lebih memahami materi yang meningkatkan hasil belajar siswa. Sejalan dengan penelitian yang dilakukan oleh Bekti Wulandari ${ }^{(16)}$ bahwa hasil belajar siswa yang diajar menggunakan metode PBL lebih baik dibandingkan dengan hasil belajar siswa yang diajar menggunakan metode demontrasi.

Hipotesis yang diajukan selanjutnya dalam penelitian ini menyatakan bahwa terdapat perbedaan gain hasil belajar antara siswa yang diajar dengan metode $P B L$ dengan siswa yang diajar dengan metode pembelajaran demonstrasi diterima. Rata-rata gain hasil belajar metode $P B L$ lebih tinggi dibandingkan dengan rata-rata gain hasil belajar metode pembelajaran demonstrasi ( $\overline{\mathrm{X}}$ $\left.\mathrm{A}_{1}=36,62>\overline{\mathrm{X}} \quad \mathrm{A}_{2}=24,48\right)$. Hal ini menunjukkan bahwa metode $P B L$ lebih unggul dibandingkan dengan metode pembelajaran demonstrasi. Dari uraian di atas, didapat bahwa siswa kelompok $P B L$ setelah diberikan perlakuan terlihat adanya peningkatan hasil belajar yang lebih tinggi daripada peningkatan hasil belajar menggunakan metode pembelajaran yang telah diterapkan.

\section{SIMPULAN}

Berdasarkan hasil penelitian, analisis data serta pembahasan maka dapat diambil kesimpulan sebagai berikut: (1) Terdapat perbedaan kemampuan berfikir tingkat tinggi siswa pada mata kuliah praktik jaringan komputer antara siswa yang diajar dengan metode PBL dengan siswa yang diajar dengan metode demonstrasi. Dari data kemampuan berfikir tingkat tinggi siswa, menunjukkan bahwa kemampuan berfikir tingkat tinggi siswa yang diajar dengan metode $P B L$ lebih tinggi dibandingkan dengan kemampuan berfikir tingkat tinggi siswa yang diajar dengan metode pembelajaran demonstrasi ( $\overline{\mathrm{X}}$ $\mathrm{A}_{1}=87,05>\overline{\mathrm{X}} \mathrm{A}_{2}=74,86$ ); (2) Terdapat perbedaan hasil belajar siswa pada mata kuliah praktik jaringan komputer antara siswa yang diajar dengan metode PBL dengan siswa yang diajar dengan metode demonstrasi. hasil belajar siswa yang diajar dengan metode $P B L$ lebih tinggi dibandingkan dengan hasil belajar siswa yang diajar dengan metode pembelajaran demonstrasi ( $\overline{\mathrm{X}} \mathrm{A}_{1}=80,05$ > $\overline{\mathrm{X}} \mathrm{A}_{2}=70,02$ ); dan (3) Peningkatan hasil belajar siswa mata kuliah praktik jaringan komputer yang diajar dengan metode PBL lebih baik daripada peningkatan hasil belajar siswa yang diajar dengan metode pembelajaran demonstrasi yang sudah diterapkan. Peningkatan hasil belajar siswa yang diajar dengan metode $P B L$ lebih tinggi dibandingkan dengan hasil belajar siswa yang diajar dengan metode pembelajaran demonstrasi ( $\left.\overline{\mathrm{X}} \mathrm{A}_{1}=36,62>\overline{\mathrm{X}} \mathrm{A}_{2}=24,48\right)$.

\section{REFERENSI}

[1] Efendi, Agus. E-learninng berbasis schoology dan edmodo: ditinjau dari motivasi dan hasil belajar siswa SMK. Yogyakarta : 2017. Elinvo (Electronics, Informatics and Vocational Education), 2(1), 49-58. ISSN 2477-2399 (online); ISSN 2580-6424 (print).

[2] Destiana, B. \& Utami, P. Urgensi kompetensi pedagogik guru vokasional pada pembelajaran abad 21. Yogyakarta : 2017. Elinvo (Electronics, Informatics and Vocational education), 2(2), 211222. ISSN 2477-2399 (online); ISSN 2580-6424 (print).

[3] Maggi, S and Claire, H.M. Foundations of problem-based learning. New York : Open University Press, 2004.

[4] Barbara, B. Levin. Energizing teacher education and profesional development with problem based learning. Alexandria : ASCD, 2001.

[5] Linda, T and Sara, S. Problems as possibilities: problem-based learning for K-16 education. Alexandria: ASCD. Alexandria : ASCD, 2002. 
[6] Tan, Oon-Seng. Problem based learning innovation: Using problems to power learning in the 21st century. s.l. : Cengage Learning, 2003.

[7] Glazer, E. Problem based instruction from emerging perspectives on learning, teaching, and technology. [Online] 2001. [Cited: Mei 31, 2013.] http://epltt.coe.uga.edu/index.php?title=P roblem_Based_Instruction.

[8] Amir, M. Taufiq. Inovasi pendidikan melalui problem based learning. Bagaimana pendidik memberdayakan pemelajar di era pengetahuan. Jakarta : Kencana Prenada Media Group, 2009.

[9] Utami, P \& Pardjono. Perbedaan Jigsaw II dan GI terhadap pemahaman konsep dan pemecahan masalah pada kompetensi mendiagnosis permasalahan pengoperasian PC dan peripheral ditinjau dari motivasi belajar. Yogyakarta : 2013, Jurnal Pendidikan Vokasi, 3(2), 234-250. ISSN 2088-2866 (print); ISSN 24769401 (online).

[10] Erik, D.G. \& Anette, K. Characteristics of problem-based learning. 2003, International Journal Engng Ed., 19(5), 657-662.
[11] Ball, A.L. \& Garton, B.L. Modeling higher order thinking: the alignment between objectives, classroom discourse, and assessment. 2005, Journal of Agricultural Education.

[12] Anderson, O.W. \& Krathwohl, D. R. A taxonomy for learning, teaching, and assessing: a revision of bloom's taxonomy of educational objectives. Newyork : Longman, 2001.

[13] Blessing, L.T.M. \& Chakrabarti, A. DRM, A design research methodology. London : Springer, 2009.

[14] Sugiyono. Metode penelitian kuantatif kualitatif dan R\&D. Bandung: Alfabeta, 2011.

[15] Adang, J.S. Mengembangkan Kreativitas dalam Berpikir Melalui Pengajaran Sains. Bandung : IKIP, 1995, Jurnal Pengajaran MIPA.

[16] Wulandari, B. \& Surjono, H.D. Pengaruh Problem Based Learning terhadap Hasil Belajar ditinjau dari Motivasi Belajar PLC di SMK. Yogyakarta : 2013, Jurnal Pendidikan Vokasi, 3(2) 